\title{
Home beyond Borders and the Sound of Al-Andalus. Jewishness in Arabic; the Odyssey of Samy Elmaghribi
}

\author{
Jessica Roda ${ }^{1, *(1)}$ and Stephanie Tara Schwartz ${ }^{2, *}$ \\ 1 School of Foreign Service, Center for Jewish Civilization, Georgetown University, Washington, DC 20056, USA \\ 2 Association for Canadian Jewish Studies, Montreal, QC H3G 1M8, Canada \\ * Correspondence: jr1791@georgetown.edu (J.R.); stephanieschwartzphd@gmail.com (S.T.S.)
}

Received: 19 October 2020; Accepted: 11 November 2020; Published: 16 November 2020

check for updates

\begin{abstract}
In their conversation about music, Edward Said and Daniel Barenboim discuss a process of seeking home in music and literature. For Moroccan-Jewish superstar Samy Elmaghribi (Solomon Amzallag), who migrated to France and Israel and then settled for most of his life in Montreal, Canada, the reference to Al-Andalus through the sound of the nouba became his home. Beginning his career in his native country of Morocco as a singer and composer of modern Moroccan music, in Montreal, Samy Elmaghribi became the cantor in the Spanish and Portuguese Synagogue, the oldest Jewish congregation in Canada. Based on ethnographic research and investigation within the archives of the artist, the authors suggest that Samy Elmaghribi created a sense of home in music, a homeness, one that transcends our present understanding of Arabness and Jewishness, religiosity and secularism, tradition and creativity. Focus on Samy Elmaghribi, an artistic persona emblematic of his generation, demonstrates how the contemporary reassessment of renowned Jewish artists' North African heritage is often misread in light of the political present. This example encourages us to rethink the musical legacy to which these North African Jews contributed beyond what is labelled Judeo-Arabic, traditional, religious, or secular.
\end{abstract}

Keywords: home; Samy Elmaghribi; Al-Andalus; Arab; Jewish; Canada

\section{Introduction}

People ask me how I can sing

And agree to be a cantor

I will never abandon my art.

I prayed to God and entertained people

I've prayed and sang since my childhood

While I was good with God and people

I will be "El Maghribi" all my life

Samy who loves you all

Salouni En nass (People Ask Me)

On the evening of 21 February 2015, the halls of the 4th floor of the Belgo Building, a center for contemporary arts in the heart of downtown Montreal, echoed with the sounds of oud, violin, and derbouka. ${ }^{1}$ Visitors who entered the gallery that evening were greeted with a range of Montreal

1 Jessica Roda and Stephanie Tara Schwartz wishes to acknowledge both the Fonds de recherche Société et Culture du Québec and the Social Sciences and Humanities Research Council of Canada (SSHRC) for supporting this research through 
artists and cantors performing songs in Arabic and Hebrew. Behind the performers was a wall of record covers in a loud array of pinks and greens. To the left, a Moroccan style divan draped with curtains was located, and to the right a wall of concert posters, sheet music, maps, and descriptive text panels. Some people sang and danced along, others documented the event on their mobile phones: a curious and enthusiastic audience. The exhibit Sacré-Profane: Samy Elmaghribi, held as part of the annual all-night arts festival Nuit Blanche à Montréal, celebrated the life and work of renowned Moroccan Jewish star of Andalusian music Samy Elmaghribi, the stage name of Montreal cantor (hazzan) Salomon Amzallag (19 April 1922-9 March 2008), and brought a little-known aspect of Arabic culture from the Maghreb to the Québécois audience. ${ }^{2}$

Sacré-Profane: Samy Elmaghribi provides a useful starting point to reflect on the question of home for immigrants, for diaspora and more particularly for Arab-Canadians, and all those nostalgic for this often-mythicized, cosmopolitan urban life in the Arab world. The exhibit was held in the aftermath of Quebec's Charter of Values debate, inspired by a Parti Québécois proposal to forbid public employees, including doctors and daycare workers, from wearing "ostentatious" religious garments (hijabs, kippahs, turbans, large crosses) (Amiraux and Koussens 2014). The divisiveness of that proposal, though eventually defeated, was a reminder of the precariousness of the concept of home, a place that can become hostile and dangerous for those deemed racially or religiously foreign to nationalist frameworks. Following Daniel Barenboim and Edward Said's conversation in Parallels and Paradoxes: Explorations in Music and Society (2004), this paper discusses homeness as created by Amzallag/Elmaghribi. Here, the concept of homeness involves the conceptual quality of establishing a base that one can leave and desire to return to, the creation of a sense of home that exists beyond national borders and territories, which also transcends our present understanding of Arabness and Jewishness, religiosity and secularism, tradition and creativity. Based on an ethnography on Samy Elmaghribi's legacy in Montreal and Morocco from the past to the present, as well as research in the family archives in Montreal, we argue that Elmaghribi established a musical home in Al-Andalus.

As one of the superstars of Andalusian music, who had to reinvent himself in Canada and Quebec, Amzallag created a homeness through music that blurred several boundaries between tradition/creation and secular/sacred, rooting himself as a Moroccan Jew in Montreal yet also transcending geographical territory and time. This music, anchored in the heritage from $\mathrm{Al}$ Andalus that he received in Morocco, symbolized a home for individuals nostalgic for this mythical past. A mobile home-presented as an "imagined space of toleration, free from violence, invoking the past of coexistence between Jews, Christians and Muslims" (Boom 2013, p. 161)—created thanks to the intangible dimension of music. Al-Andalus evoked the mythical "Golden Age" or so-called Convivencia period where (it is claimed) the coexistence of Judaism, Christianity, and Islam caused a culture for knowledge and the arts to flourish in the southern region of the Iberian Peninsula under Muslim rule between the 8th and 13th centuries (Roda 2014; Glasser 2016). Al-Andalus is considered as the birthplace of what is today called "Andalusian music", which, after the expulsion of Muslims and Jews from Spain and Portugal, migrated across the Mediterranean and developed into distinct but related poetic-musical traditions in Morocco, Algeria, Tunisia, and Libya. Andalusian music is based on the nouba, "an ensemble of songs and instrumental pieces that are performed together according to reasonably well-defined rules" (Davila 2015, p. 150). The mid-20th century mass emigration of North Africans carried this genre of "Arab classical music" into new diasporic networks. As one of the stars of this genre, who also

postdoctoral fellowships. The authors owe a tremendous debt of gratitude to Yolande Amzallag for her confidence, faith, and friendship. She gave us access to the archives and her cultural, social, and familial universe. Without her support and reliable relationship, this research would not have been possible. A special thanks to all the participants in the research who agreed to spend time narrating their past with Salomon Amzallag.

2 The exhibit was curated by Stephanie Tara Schwartz as part of her SSHRC funded postdoctoral fellowship (2014-2016) in partnership with the Museum of Jewish Montreal, the Samy Elmaghribi Foundation, and Dr. Yolande Cohen's research group Histoire, femmes, genre et migrations at UQÀM. The authors of this article collaborated with Yolande Amzallag in research and writing text panels for the exhibit. 
participated in its modernization (Silver 2020), Amzallag left Morocco in the late 1950s, lived in France for five years, and then settled in Montreal where he had to reinvent himself. In his new hometown, he felt itinerant (Amzallag 2017) and created a homeness through music that he shared with others at the synagogue. This homeness blurred the boundaries between tradition and creation, secular and sacred: categories commonly portrayed as opposites in the context of Quebec's quiet revolution. This homeness also rooted Amzallag as a nationalist Moroccan Jew in Montreal. Arabness and Jewishness were not antagonistic for the artist, and indeed, for many others, Maghrebi Jewish musicians drew on the rich heritage of Arabic musical systems and contributed to nationalist music at the time of independence.

In what follows, we first explain the development of the growing academic and political interest in the Jewish contribution to North African music during the colonial and postcolonial periods. We further examine its effect on the misread contemporary reassessment of the North African heritage of renowned Jewish artists. We then outline Amzallag's journey from Moroccan star of popular Arabic music to Montreal cantor and discuss his creation of the "Elmaghribi style" in both Canadian Jewish liturgy and secular Arabic music. Finally, we look at the artist's odyssey between the presumed binaries of sacred vs. secular, Arab vs. Jewish, and tradition vs. innovation in relation to Barenboim and Said's metaphor of home within music and literature. This paper thereby suggests that Samy Elmaghribi creates a homeness in music, a homeness in Al-Andalus that transcends our contemporary understanding of Arabness and Jewishness, religiosity and secularism, tradition and contemporaneity. In conclusion, we will see how this homeness is reinvented today to respond to the challenges of modern times.

\section{Performing Jewishness in Arabic: Decline, Recognition, and Politicization}

There is a small but growing academic interest in Jewish participation in North African popular and classical music. Interestingly, while an entire generation of Jewish artists, singers, and composers originally from the Maghreb participated alongside their Muslim coreligionists in Arabic musical production both pre- and post-independence, it is only recently that we observe a growing academic interest (Glasser 2016). Samy Elmaghribi's story is part of the larger story of the preeminence of Jewish musicians in the North African recording industry under French colonialism. These include musicians such as Zohra Al Fassiya (Morocco), Salim Halali (Morocco), Albert Suissa (Morocco), Jo Amar (Morocco), Louisa al-Israïliyya (Algeria), Reinette l'Oranaise (Algeria), Line Monty (Algeria), Rene Perez (Algeria), and Lili Boniche (Algeria).

The ethnomusicologist Edwin Seroussi wrote an entry on Samy Elmaghibi for the Encyclopedia of Jews in the Islamic World (Seroussi 2010). In 2014, Mohamed El Haddaoui published La musique judéo-marocaine: un patrimoine en partage in which he reclaimed Samy Elmaghribi as a Moroccan national figure and argued that Moroccan Jewish musical history, with the looming presence of its Moroccan Jewish stars in the early 20th century, was at risk of being forgotten and should instead be recognized as a part of the national heritage (El Haddaoui 2014).

The growing academic interest in Jewish stars, and more specifically Jewish musical repertoire from the Arab countries of that historical period, has been developed in tandem with the reassessment of this musical heritage on-stage. There, the Jewish participation is politicized, reinvented, and labelled as Judeo-arabic or, more recently, as Chgouri. Indeed, these Jewish artists and their Arabic repertoire originating in North Africa during this period of transition towards new nation-states were understood as part of a common musical heritage. Samy Elmaghribi was presented as a Moroccan performing in Arabic on the national and international stage. Yolande Amzallag, Samy's youngest daughter, articulated that in these terms:

"You know, my father was first of all a Moroccan artist. He performed in Arabic and was a star for the nation. Of course, he was proud to be Jewish, performed also in religious Jewish settings, but he was mainly renowned for his creation and interpretation of a "modern" Moroccan songbook and soundtrack, deeply rooted in traditional Moroccan popular and classical music, which was widely broadcast in Morocco and Algeria through radio and recordings. Part of this narrative, we Jews and Muslims share, yes, but that was never 
announced so politically; it was natural to be Jewish or Muslim and perform Chaabi, Melhun or Hawzi in Morocco or Algeria, and this repertoire was never designated as "Jewish music". As for the term "Chgouri", my father never talked about such a genre, but it is recently being assimilated to the recollection of Jewish presence in Morocco. In fact, I lately learned that it is a hybrid genre of popular music, mixing Algerian and Moroccan influences, like Hawzi and Melhun, Ala and Gharnati, that was attributed to Jews because of the communications between communities that enabled them to preserve and pass on various music genres across generations and beyond political or territorial boundaries. In other words, Jews were the safekeepers of traditional Arab-Andalusian musical traditions across the Maghreb, mainly through liturgy, and in this capacity, they fostered hybridity. However, Chgouri music wasn't the exclusive domain of Jews, and Muslim musicians often came to the Mellah to draw new inspiration or recover forgotten musics of the past that Jews had preserved. Besides my father and other famous Jewish musicians, Muslim interpreters of the chgouri genre include Shkara and Houcine Slaoui." (Interview with Yolande Amzallag, October 2018)

Yolande Amzallag communicated a clear transformation, reinterpretation, or even reinvention (Hobsbawm and Ranger 1983) of what we define as the performance of Jewishness in Arabic. It was once considered a common experience to be Jewish and singing in Arabic, performing alongside Muslims, providing national soundscape during the time of decolonization (Silver 2017). Today, by contrast, performing Jewishness in Arabic is seen as controversial, involving political and identity claims. Indeed, the emergence of Arab and Jewish nationalisms led to a reinvention of the past in light of current political tensions as well as precipitated the delineation of new ethnic categories linked to the experience of exile (Gottreich 2008).

After several decades of relative silence regarding these Jewish artists from North Africa, we see an interesting revival that occurred under the label of Judeo-Arabic music. While, during Salomon Amzallag's time, performing Jewishness simply meant singing in Arabic, today it signifies singing Judeo-Arabic music or performing Arab-Jewish culture: a controversial term used by artists, notably in Israel, who want to reconnect with their Arabness. This performance can also involve claiming dialogue and peace among Jews, Christians, and Muslims, a dialogue anchored in the mythical Al Andalus.

From this perspective, international, national, and local cultural agencies in countries where there are significant Maghrebi Jewish and Muslim populations, such as France and Canada, as well as in Morocco, invest in the promotion of dialogue and understanding among Jewish, Christian, and Muslim communities through the medium of musical performances and practices. World Music Festivals in Europe (Festival des musiques sacrées de Paris, Suds à Arles, Tres Culturas de Murcia, etc.), Canada (Festival du monde arabe, Festival Sefarad), and Morocco (Festival des Andalousie Atlantiques, Festival de musique sacrée de Fez) take advantage of this phenomenon by staging and promoting artists, essentially performing reconciliation between Jews and Muslims, notably in the context of countries where there are important tensions between Muslim and Jewish populations because of the importation of the Israeli-Palestinian conflict (Gordon 2003; Kaminsky and Kurk 1983; Roda 2014).

As the historian Christopher Silver $(2017,2020)$ points out, Salomon Amzallag's success, and the success of other Jewish musicians and composers of his generation, is part of a larger story of the preeminence of Jewish musicians in the North African recording industry under French colonialism. This success further highlights their participation in a shared Arabic musical heritage. Silver writes: "Alongside the nationalist revolution afoot in Morocco at mid-century, Samy Elmaghribi ushered in a musical revolution. In whatever form Moroccans imagined their future (without France), Samy Elmaghribi (Samy the Moroccan) cleaved closely to that vision. In more ways than one, he appeared to embody their destiny" (Silver 2017, p. 183). Here, the historian points to the contradictory fact that Jewish musicians provided the soundtrack for nationalist movements in North Africa who increasingly defined themselves in exclusionary Arabo-Muslim terms. Ironically, it is in Israel that Silver discovered the music that became the subject of his research. 
Salomon Amzallag's individual journey is part of the broader story of North African Jewish migration and the forging of new diasporic networks around Sephardic, Mizrahi, Francophone, or Arab-Jewish identities. ${ }^{3}$ Moroccan Jews began to immigrate to Canada in 1957 in the year following Moroccan Independence from the French Protectorate it had been held under since 1912, primarily settling in Montreal and Toronto. As Francophones from an Arabic-speaking country, Moroccan Jews faced many barriers vis-à-vis the established Jewish community in Quebec who, by the 1950s and 1960s, were primarily Ashkenazi and Anglophone. These challenges were also replicated on a broader social level where, as Jews, they faced barriers vis-à-vis the majority population of Catholic Quebecois (Miles 2012; Roda 2015). Between and in relation to these two groups, Moroccan Jews established many self-help organizations such as the Association Sépharade Francophone (ASF) (which began as Groupement de juifs nord-africains and today is called the Communauté Sépharade Unifiée du Québec (CSUQ)). Community leaders identified themselves as Sephardic Jews, linking themselves to a prestigious history of Jews exiled from Spain and Portugal and that of North America's first established Jews. The activism of Moroccan Jews and their struggle to integrate into Quebec society are depicted in Jacques Bensimon's (1977) National Film Board documentary 20 ans après. Bensimon documented the struggle of Francophone Jewish youth forced to attend English language school (Jews attended English Protestant schools under Quebec's confessional school system). He documents the perception of these youth as "Juifs Catholiques" or rich capitalists by their non-Jew Quebecois peers. Finally, he recounts the Association Séfarade Francophone's struggle to build an independent community center for Francophone Sephardic youth despite the Ashkenazi Jewish community leaders' concern for Jewish unity under the rise of Quebec nationalism. His work reveals the diversity of Montreal Sephardic activism in the 1960s and 1970s and its relations to the local and global politics of postcolonial dissent (Schwartz 2017, p. 74).

Music was Amzallag's chosen avenue for integration into Montreal, both on the bimah (a raised platform from which the Torah is read) of the Spanish and Portuguese Synagogue and in his living room, which he converted into a Moroccan salon from where he hosted parties, jams, and performances. His daughter, Yolande Amzallag, related:

The synagogue was a bridge between the Arab culture we came from and which we also were an expression of and ... Western culture. Because it was a way of asserting our difference in a more accepted way. Because it was a synagogue, it was a more accepted institution, an official public institution. It officialised our identity ... Arab culture was not appreciated. And was not as well-known or appreciated as it is today, and it was even depreciated... I think that what my father was able to achieve through his work at the synagogue was to assert his culture and to integrate into the Ashkenazi majority without renouncing his origins. It was very structuring for us. It gave us strength. (Amzallag 2017, 18:28-20:55)

In the years since Salomon Amzallag's passing in 2008, his contributions to Andalusian music have been honored in Canada, Israel, and Morocco. For example, the 2016 edition of Festival des Andalousies Atlantiques d'Essaouira featured a tribute to Samy Elmaghribi and the announcement of the creation of a sub-office of the Samy Elmaghribi Foundation in Rabat. The event demonstrated

3 For more on this nomenclature, see Ella Shohat (2006) (on Arab Jews and Mizrahim), Benbassa and Rodrigue (1995) on Sephardim from the Ottoman Empire, Harvey E. Goldberg (1996) on Sephardim and the Middle East, Marglin (2016) on Jewish and Muslim relation in Morocco (2016), Emily Benichou Gottreich (2006, 2008, 2020), Lital Levy, Bashkin (2012) on Iraqi Jews, Cohen and Schwartz (2017) for a historiography of how Moroccan Jews in Canada have engaged with some of these identifying terms over time, Schwartz (2017) on protest movement and Mizrahim in Quebec, and Roda (2018) on Sephardim from the Ottoman Empire who migrated to France. Moroccan Jewish leaders chose to refer to themselves as "Sephardim" in Quebec, though many of them had roots in Morocco that predated the expulsion of Jews and in Spain and Portugal in the 15th century. The term "Mizrahim", used in Israel to refer to the Jews of North Africa and the Middle East, or Arab Jew are less commonly used as identifying terms in Montreal. The influence of the term "Sephardic" has masked the diversity of other non-Ashkenazi groups such as the Iraqis, Yemenite, and even Iranian. For example, the Iraqi Jews have defined themselves over time as Sephardi, Arab, Iraqi, and Babylonian (Joseph 2017). 
the extent to which Samy Elmaghribi's music has touched many generations of Moroccans and is still celebrated in Morocco today. Elmaghribi's continued legacy is enhanced by the homeness his music invokes for the North African Arabic-speaking diaspora.

\section{Samy Elmaghribi and Salomon Amzallag. From Moroccan Superstar to Montreal Cantor}

Salomon Amzallag was born in 1922 to a Jewish family in Safi, Morocco. At the age of four, Amzallag moved with his family to Rabat, the Moroccan capital. He showed a passion and talent for music at this very early age. Growing up in Rabat, he was surrounded by the sounds of piyutim (Jewish liturgical poetry) at home, in synagogue, and Talmud Torah (Jewish religious school). Meanwhile, he was exposed to French chanson and Zionist folksongs at the Alliance israélite school, whereas Andalusian music, Egyptian stars Mohamed Abdel Wahab and Um Kulthum, jazz, rumba, and other popular genres found their way to him in local clubs, cafés, and on the radio (Silver 2017). In Rabat, the oral traditions of Andalusian music were handed down to him by renowned masters in gharnati music (arabo-andalusian music from Tlemcen, Algeria) such as Mohamed ben Ghabrit. ${ }^{4}$ Indeed, like many Moroccan Jews, Amzallag was known as a performer of gharnati, and he was its main popularizer via the recording industry in the 1950s and 1960s (Glasser 2008, p. 332). Already an accomplished singer, he learned to play the oud and later studied at the Conservatory of Music of Casablanca, where he moved in his early 20s. Inspired by Algerian masters of Andalusian music such as Reinette l'Oranaise and Cheikh Zouzou, Salomon Amzallag dutifully interpreted their repertoire, soon penning his own popular songs in a variety of genres and founding Samy's Boys (Figure 1). In 1948, he was tapped by L. A. Vadrot, the local head of the most important label in North Africa, Pathé, which was the European label that dominated the growing music industries in North Africa. He left the recording studio with the stage name Samy Elmoghrabi (Samy the Moroccan, later changed to Samy Elmaghribi), underscoring his attachment to the Moroccan nation (Silver 2020). European labels such as Pathé sought out local stars from around the world to increase their sales locally (Gronow and Saunio 1999; Gronow 1981). From 1948 on, Samy Elmaghribi increased his fame. While touring in Paris and performing at the cabaret El Koutoubia in the 1950s, he met popular Algerian Jewish artists Line Monty and Lili Labassi. In 1952, he established his own record label Samyphone (Figure 2), the first independent record label in the Maghreb, opened a record store in Casablanca, and released Omri ma nenssek Ya Mamma (I will never forget you, Mama). Written for his mother who passed away when he was fifteen, this would become one of his most popular songs. Samy Elmaghribi sang in Arabic and drew upon the literary form of the language in his compositions (Lugassy 1977, p. 4). Another of his early songs was Alef ehneyya ouehey (A thousand and one welcomes), composed in 1955 for Moroccan King Mohamed V after his return from exile in Madagascar to St-Germain-en-Laye in France.

4 The Ben Ghabrit family is an Algerian family from the Tlemcen region, well-known in the world of gharnati music. Mohamed was particularly known in the Moroccan capital (Rabat) because he attended the Congress of Arab Music in Cairo as part of the Moroccan delegation and was then transferred from there to Rabat and was a pillar in the development of gharnati music in the Moroccan capital (Glasser 2008). 


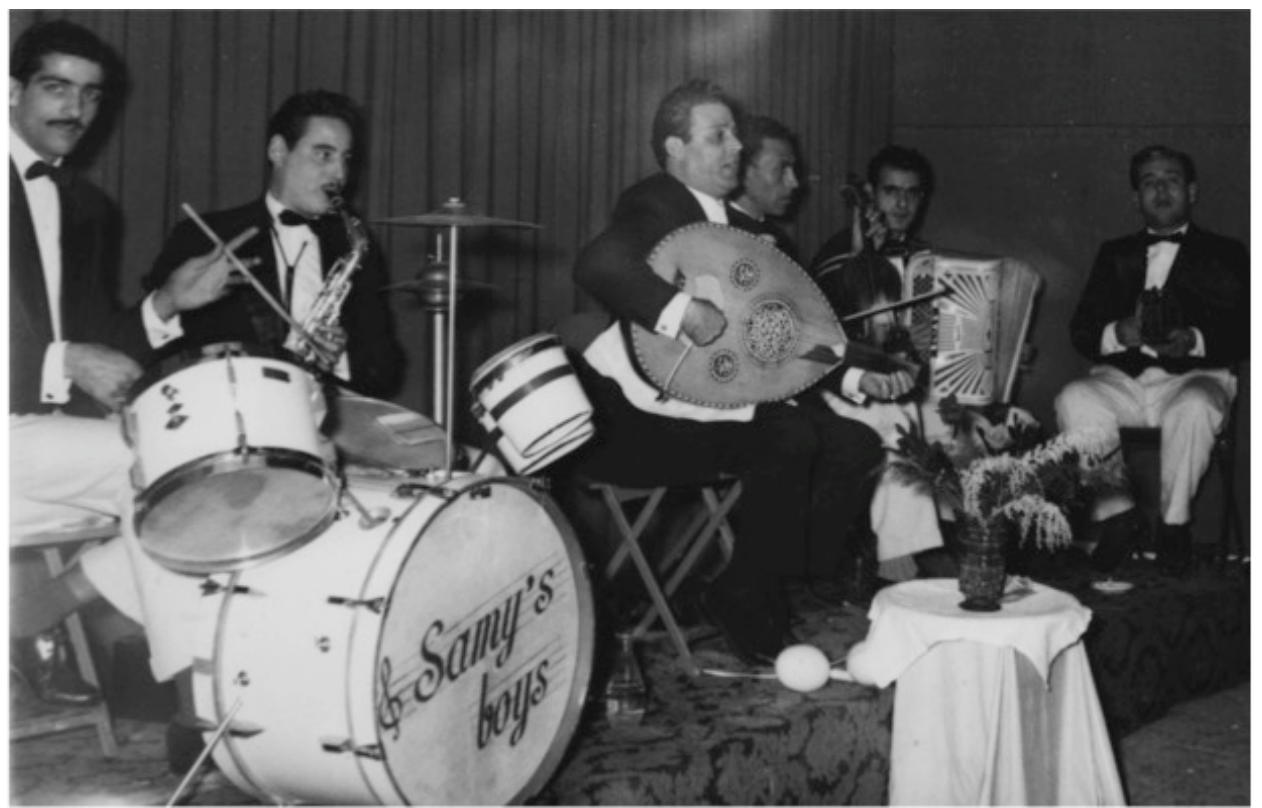

Figure 1. Samy's Boys in Concert in the early 1950s (Courtesy of Yolande Amzallag, Foundation Samy Elmaghribi).

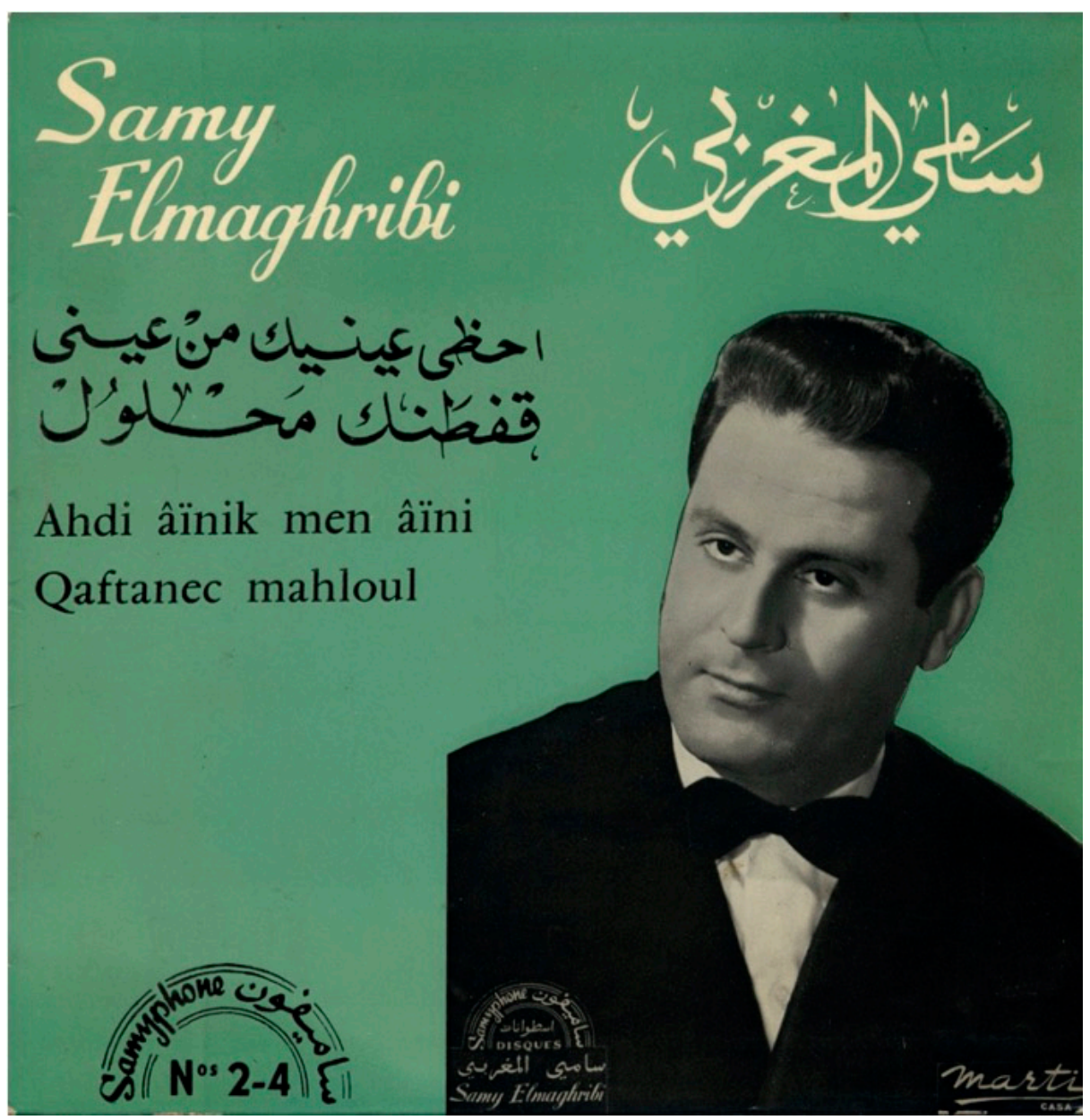

Figure 2. Cover of Samyphone number 2, composed in 1952 and recorded in 1955. (Courtesy of Yolande Amzallag, Foundation Samy Elmaghribi). 
The originality of his compositions and arrangements of classical songs, his charisma, his access to the most prestigious and famous record company, as well as his visibility in the media (TV, press, and radio) contributed to his national and international success among Arab Jewish and Muslim speaking audiences composed of both elite and working classes. Indeed, Elmaghribi became a Moroccan star celebrated on the national radio and television and performed for the sultan and the crown prince, as well as in cabarets across France, Morocco, and Algeria with Jewish and Muslim artists alike. ${ }^{5}$ There he participated in the dissemination of "Moroccanism" - a nationalism centered on the Moroccan monarch and the Moroccan people (Silver 2020). His compositions transcended the boundaries between classical Andalusian music and pop music by using both classical Algerian noubas as well as elements of melhoun and haouzi (popular lyrics based on the classical Andalusian music system).

Playfulness marked the success of Elmaghribi's early career, which is striking given its occurrence amidst the tumult of decolonization and independence struggles across North Africa and the Middle East. For example, Elmaghribi signed a contract with Monsieur Bouchaib ben Regrangui "El Bidaoui" for a series of performances between April 23 and May 12 in 1957 for a show in which El Bidaoui would perform a sketch disguised as a woman along with Abdesslem ben Abdelkader "El Meknassi" in the role of Hadj and Abdelouahad el Medkouri in the role of a Jew (Samy Elmaghribi Foundation Archives 1957, contract GL63483, April 4). Contracts between Elmaghribi and the musicians and artists he employed in the late 1950s included protection against liabilities provoked by "national catastrophes, riots, civil war, [venue] closure by superior authorities, and national mourning" (Samy Elmaghribi Foundation 1958, contracts AT89982, AT38512). This playfulness can also be observed in the way Elmaghribi's music crossed the presumed binary of sacred and secular. Despite the decidedly secular lyrics of Elmaghribi's 1956 Kaftanek mahloul (Your Robe is Open), a 1959 Moroccan field recording taken by American author and composer Paul Bowles captured a performance of the Hebrew prayer El hay ram gadol sung by Rabbi David Buzaglo to the tune of Elmaghribi's hit in the Ben Amara Synagogue of Meknes (Silver 2015).

The political situation in Morocco was part of the complexity of factors that would inspire the Amzallag family, like thousands of Jews across North Africa and the Middle East, to migrate from their homes to Israel, France, North America, and elsewhere (Cohen 2012; Bin-Nun 2014). However, contrary to what is known as the Jewish exodus from Morocco, which took place between 1948 (birth of the State of Israel) and 1956 (Independence of Morocco), Samy Elmaghribi moved with his family to Paris $^{6}$ three years after the independence (1959) and kept his recording company in Morocco for several years. Upon his arrival in Paris, he opened a second branch of Samyphone. In 1967, heeding the beckoning of his recently immigrated fans and friends, Samy Elmaghribi was encouraged to audition to become the cantor of the Spanish and Portuguese Synagogue, Canada's oldest Jewish congregation established in 1768. Although he was never formally trained as a cantor, he conducted religious services and performed Jewish liturgical music throughout his career. The star was invited to enhance and support the burgeoning Moroccan Jewish community in Canada through his new occupation at the Spanish and Portuguese Synagogue, which wanted to attract new members from among Moroccan Jewish newcomers to renew and reinvigorate its declining membership. Amzallag enjoyed a long and successful career as the hazzan of the Spanish and Portuguese Synagogue, remaining in the position until 1984. In the section that follows, we elaborate on the homeness Elmaghribi created for Jewish audiences upon his arrival in Montreal through his work at the Spanish and Portuguese Synagogue.

5 To learn more about the success of Samy Elmaghribi in Morocco, read Christopher (Silver 2020).

6 In 1955, Samy Elmaghribi had been a temporary resident in Paris, where he used to travel for work, and received a contract to perform at Soleil d'Algérie, a North African Cabaret (Silver 2020). 


\section{Making Home in Montreal: From "Elmaghribi Style" in Jewish Liturgy to the Transmission of Al-Andalus}

According to his daughter, Yolande, Amzallag experienced culture shock upon his arrival in Montreal in 1967 when he began in his new position at the Spanish and Portuguese Synagogue. After experiencing an initial sense of displacement upon moving to France from Morocco and a second in Canada, the idea of creating a new home for himself and his family became central. Contrary to the Parisian experience, where the recreation of home was made through the common Andalusian heritage that he could exchange with other Arab Jewish and Muslim professional artists from the Maghreb, in Montreal, Salomon Amzallag had to recreate this environment by himself. In Montreal, he did not find belonging in any artistic community and felt particularly isolated. He felt the need to reconstruct his own artistic place in his home. Thus, in private spaces, he began giving music lessons (primarily voice and oud as well as Arabo-Andalusian music theory) and often organized events when musicians performing classical Arabo-Andalusian music were in town from abroad. With his new position at the synagogue, he increased his focus on Spanish-Portuguese and Ashkenazi liturgical music: the sacred realm of his congregation he needed to enter. Throughout his life, Salomon Amzallag always embodied his position and was faithful to the place that gave him structure and home. From this perspective, his public musical performances always reflected his social position. In Morocco, he embodied the superstar of modern Moroccan music but in Montreal he radically changed his public figure to become a cantor of a renowned religious place. In an interview with journalist Charles Lugassy (1977), he stated "I am free in my actions ... but I believe that it is incompatible to demand the grace of G-d while producing shows in front of dancers. These restrictions, I imposed them myself [rather than the synagogue] out of respect for my function of which I am proud and honored to fulfill". However, though he was very respectful of the social borders differentiating his performances in cabarets and synagogues, his knowledge of Arabo-Andalusian music was used on both stages as his central tool to transcend the dichotomy between tradition and creation. The private and emotional connection with Arabo-Andalusian music led Amzallag to create a private home that transcended national borders and divisions between visitors from Morocco, Israel, France, and the United States, all parts of the North African Jewish and Muslim diaspora. Though he persistently created bridges by mobilizing this common heritage, Amzallag was always pragmatic when it came to his professional position.

When he started at the Spanish and Portuguese Synagogue ${ }^{7}$, Amzallag inherited a mixed congregation of Eastern European Jews and North African Jews (primarily Moroccans) as well as Jews from the Mashreq (Iraq, Egypt, Lebanon). The Spanish and Portuguese Synagogue used a liturgy that blended Ashkenazi and Anglo-Sephardic traditions with an adult polyphonic choir who participated in the services (Figure 3). ${ }^{8}$ Amzallag chose to reintegrate Spanish and Portuguese melodies in the primarily Ashkenazi liturgy, based on music preserved in the synagogue's archives and developed by Abraham de Sola, the London-born Rabbi who served at the congregation from 1847 to 1882. Performing both on the stages of popular Arabic music and Moroccan synagogues, Amzallag progressively integrated North-African vocal technique into the liturgy, developing his own style, while also maintaining the Spanish-Portuguese traditions. During his career, he became particularly committed to the transmission of the Moroccan Jewish liturgy. Hazzanim (cantors) who

7 This analysis is based on ethnographic research with members of the Spanish and Portuguese Synagogue (Yehuda Abittan, Eyal Bitton, Michel Koslowski, Joseph Muyal), students (Gad Elbaz, Michael Abikhzer, Orel Gozlan, Yehuda Abittan), and family members (Esther and Yolande Amzallah).

8 The congregation of the synagogue had been founded in 1768 by British and American Jews who followed Sephardic tradition and represented an Anglo-Jewish elite. The synagogue's congregation, since its founding until the 1960s, however, had been primarily Ashkenazi Jews. When Jews from North Africa and the Middle East began to immigrate to Montreal in the 1950s, many found a first "religious" home at the Spanish and Portuguese Synagogue. Iraqi Jews, for example, who did not trace their roots to Spain and Portugal, "were not observant Jews, not uniformly ritually practicing" but "the synagogue's Orthodox conservatism and formal British-style etiquette formed a bridge for their nostalgia and a location for their sense of tradition" (Joseph 2017, p. 104). 
were trained by him in Montreal not only speak of the preservation of Moroccan Jewish liturgy, but also of Amzallag's innovation of liturgical style in terms of aural, social, cultural, and spiritual experiences. The presence of the superstar transformed the perception and performance of liturgy in the Moroccan Jewish community of Montreal as well as the role of music and the choir at the congregation. Most of the changes he made were enacted for religious and social purposes.

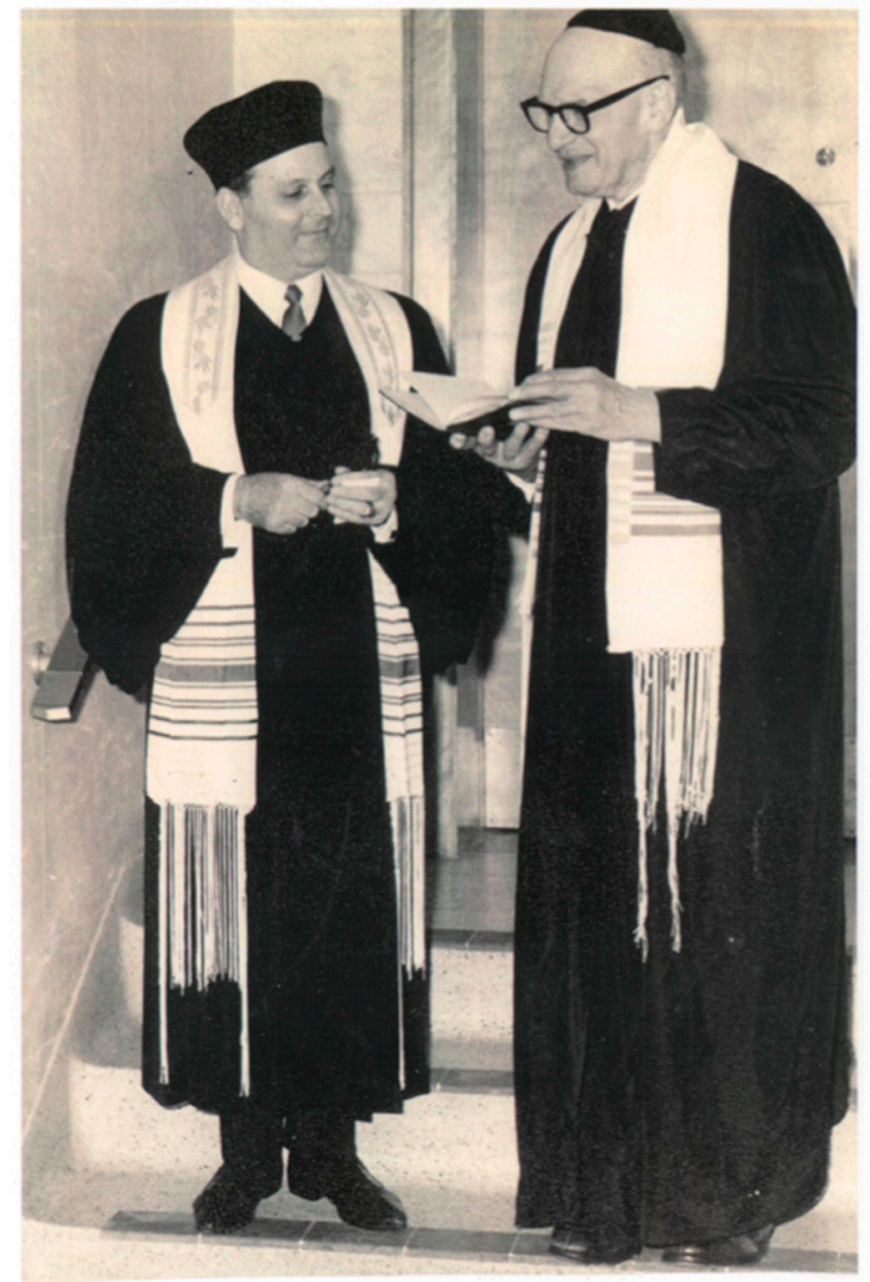

Figure 3. Cantor (Hazzan) Salomon Amzallag with Rabbi Solomon Frank at the Spanish and Portuguese Synagogue. (Courtesy of Yolande Amzallag, Foundation Samy Elmaghribi).

Knowing that the words of prayer were crucial for the liturgy, he progressively decided to stop the synagogue's polyphonic choir to concentrate instead on unison (all members of the choir would sing the same note) and a simplified musical arrangement. As Michel Koslowski (choir director when Amzallag began as Hazzan) explained, polyphony obscured the lyrics, making it more difficult for members of the congregation to participate in the service (personal communication, May 2015). Participation from the congregation was really important for Amzallag, and he wanted both members of the choir and regular attendees involved in the service. The congregants had to feel incorporated into the service and not remain mere spectators; an experience of the service that characterized Moroccan philosophy according to Amzallag. Following this idea, with the intention to involve all members and remove hierarchy within the congregation, Amzallag moved the choir from the "choir loft" situated at the upper level on the left of the synagogue, to the same level of the congregants and removed the microphone, compelling the choir to sing louder. He also changed the participation of congregants for certain prayers. He encouraged everybody to pray with him, rather than he, the hazzan, praying alone with the choir joining later. For Amzallag, the service was no spectacle, it was above all a participatory 
prayer; the hazzan guided the congregants and the choir into singing in unison. Another important change occurred in 1974, when he helped create a children's choir, initially concomitant to the adult choir. His aim was to attract more people, such as parents coming to see their children, to reduce the cost of the professional adult choir and of course to stimulate the younger generations to learn the liturgy. This could create a new generation of hazzanim knowledgable about various liturgical styles including the Moroccan one inspired by the Arabo-Andalusian system, the Spanish-Portuguese, and the Eastern-European one. Within three to four months, the children's choir (10 children) replaced the adult choir. This choir progressively became a children's choir entirely constituted by children of Moroccan origin who learned music, Spanish and Portuguese liturgy, and some elements of Moroccan tradition. Moreover, with the children's choir, Amzallag ritualized the performance and gave this generation the opportunity to develop a savoir-faire for music in the synagogue.

Cantor Amazallag did not strictly follow the Moroccan tradition of improvisation (where cantors often composed original melodies as they sang), but he did leave some room for novelty and flexibility. Beside the social change around the choir and the way the service could be experienced, Amzallag also needed to innovate in order to maintain the regular participation of the new Moroccan congregants he brought into the synagogue. To do so, he introduced a few Moroccan melodies inspired by Arabo-Andalusian music and techniques of vocal color in the cantillation characteristic of Moroccan liturgy. He used to sing with Moroccan vocal techniques including ornaments, guttural sounds, and microtones. With the introduction of new melodies, his objective was to institutionalize them and make them part of the congregation's tradition. First, he and the choir sang the new melody at Shabbat; then he repeated the process approximately every three months so the members of the congregation could learn and memorize it. After this repetition, he sang the regular and new melodies together for several following Shabbats (a process that made the new material traditional). However, this change happened only for Shabbat, not for the major holidays, and was unusual because he generally opted to preserve the core traditions of the congregation (according to Amzallag's students and collaborators Yehuda Abittan, Gad Elbaz, and Michel Koslowski).

During his time at the synagogue, he taught students and trained new cantors in the so called "Elmaghribi style", a combination of a commitment toward the musical heritage of Al-Andalus associated with the past and a constant need for contemporary innovation in light of its environment. On one hand, Samy was extremely committed to the styles of his master teachers of Andalusian music, and on the other hand he constantly thought about updating this past in relation to his social and cultural environment to make it accessible to his contemporaries. In this context as a Moroccan pop star knowledgeable of Arabo-Andalusian music such as the melhoun and haouzi, he created a new genre by integrating battery, accordion, and saxophone. He also brought in American and Latin aesthetics that were a la mode for Moroccan music. In Montreal, as a cantor at the Spanish and Portuguese Synagogue, he emphasized passing the Spanish-Portuguese and Ashkenazi liturgy on to the younger generation. All the while he also focused on integrating Moroccan songs inspired by Andalusian music to regenerate the local liturgy while many Moroccans were part of the congregation. While imparting Spanish and Portuguese and Ashkenazi melodies, he gave an entire generation of kids of Moroccan origins the opportunity to learn musical language, musical performance of ritual, Moroccan liturgical elements, and, above all, passion and pride in the Moroccan traditions. He taught his students Daniel Benlolo (Ottawa and now Montreal), Avraham Sultan (Florida), Itska Bettan (Israel), and Eyal Bitton (Toronto), all cantors located around the globe, to learn the Moroccan liturgical style while maintaining knowledge of Spanish, Portuguese, and Ashkenazi synagogue traditions. This allowed them to move from one synagogue to another no matter the prevalent musical tradition and to perform from the bimah to the concert hall: crucial skills for the current musical market (better to include a more specific term here). Through his life and work, Elmaghribi passed on a legacy of Moroccan culture so we may remember that, in the past as in the present, the dialogue between different musical, social, and cultural worlds was always, and will always remain, rich and vibrant. In traces of piyutim echoing the sounds of Al-Andalus, melismatic styles, Spanish, Portuguese, and Ashkenazi melodies and 
maqamat (Arabic musical modes), the artist's spirit lives on and is perpetuated and reinterpreted by a whole new generation. At the Spanish and Portuguese Synagogue, Amzallag's legacy is still audible and tangible. The former hazzan, Yehuda Abittan, and the current one, Daniel Benlolo, both originally from Morocco, learned the liturgy of the congregation with Salomon Amzallag and reproduced the "Elmaghribi style" both in terms of the social, cultural, and audible experiences of the service.

After 17 years of service within the mixed community of the Spanish and Portuguese Synagogue, Amzallag wanted to fully return to his Moroccan origins, to his popular stage, and to being part of a more orthodox congregation that he saw as a more "authentic" experience of Jewish practice, according to his daughter, Yolande. He felt a profound need to promote and pass on Arabo-Andalusian music to a new generation of Jews and Muslims in Montreal. Amzallag wanted to dedicate himself to this tradition alone and for this reason, in 1983, he collaborated with David Sabbah, a new rabbi who arrived in Montreal from Morocco in the 1980s. Sabbah offered him the possibility to create a unique space for Moroccan liturgy in his own way. He left the Spanish and Portuguese Synagogue to become director of the new Congrégation du Centre Rabbinique Maghen David. With this new position, he could lead integral services in the Moroccan style, return to a life filled with more performance, and focus on the instruction of Arabo-Andalusian music for the next generation.

Throughout his liturgical legacy and the activities surrounding his activity after the 17 years at the Spanish and Portuguese Synagogue, Amzallag contributed to the promotion and transmission of Moroccan music within the Jewish community and abroad. During his time at the synagogue, he often performed Moroccan popular music in Arabic, including his own compositions, for weddings and bar mitzvahs. While at his new position at Maghen David Congregation (1984-1986), he returned to popular stages in Montreal and abroad including Place-des-arts, the Montreal's prestigious concert hall. From 1986 to 1996, he retired from his cantorial position and lived in Ashdod (Israel) where he was involved in the creation of the Centre for Liturgy and Song (Merkaz Piyout Veshira) and trained choirs in Andalusian music. He was a founding member and first director of the Israeli Andalusian Orchestra in 1994. The orchestra brought together North African Jews trained in the oral traditions of Andalusian music and classically-trained Russian musicians who learned the repertoire from sheet music. Today, the orchestra is recognized as a national ensemble on the same level as the Israel Symphony Orchestra and includes Arab citizens of Israel and Jews from various cultural, musical, and religious backgrounds. In 1996, he came back to Montreal and created his own synagogue in his neighborhood where he pursued his work recording and teaching Andalusian music. Samy Elmaghribi influenced an entire younger generation of Mizrahim (Jews with origins in Arab and Muslim countries), helping them rediscover the cultural heritage of their parents and grandparents and integrate his compositions into this common heritage. He was and is a symbol of an entire generation mobilizing Al-Andalus to navigate from synagogue performances in Hebrew to on stage performances in Arabic. Crossing these cultural and linguistic spectra allowed repertoire, sounds, and savoir faire to cross worlds of experiences. The younger generation of Jewish and Muslim musicians as well as hazzanim that Elmagribhi inspired includes Lior Elmaliah, Benjamin Bouzaglo, Liz Mamane (his grand-daughter), Kobi Peretz, Neta Elkayam, Eyal Bittan, Michael Abikhzer, Orel Gozlan, Sanaa Marahati, Abir El Abed, Nabila Maan, and Henri Abittan, to name a few. ${ }^{9}$

Throughout his life, Samy Elmaghribi was dedicated to the preservation, institutionalization, and transmission of heritage of mainly Moroccan liturgy and popular music that he associated with Al-Andalus (Arabo-Andalusian music). For him, his dedication to music was a way to recreate the home he left in Morocco, a home infused with nostalgia of a time and a place he quit at the peak of his career (Silver 2020). His interest in heritage-building was in constant dialogue with his contemporary creations, his fellow generation, and debates of the time. His actions both at the synagogue and on

9 Regarding the revival of Mizrahi music and, more broadly, of Al Andalus for the Jewish diaspora, started to be of significant interest after the year 2000. The works of Edwin Seroussi (2006), Amy Horowitz (2010), Jonathan Shannon (2015), Jonathan Glasser (2008, 2016), and Ruth Davis (2015) are particularly significant. 
stage show us that, for him, preserving tradition meant focusing on transmission and reinterpretation. He clearly navigated, both during his experience as hazzan and pop singer, between solidifying existing heritage and imprinting his own individual signature. This preoccupation about the safeguarding and respecting of "traditional repertoire or practices" and the necessity to update these practices so that spiritual or musical leaders could adapt them to their times, is nothing new. Anthropologists and ethnomusicologists have shown how oral tradition is constituted by reception, reinterpretation, and transmission (Picard 2001), and is constantly modernized according to the times. In the case of Samy Elmaghribi, his experience-both at the synagogue and on stage-gave Moroccan music of Al-Andalus, both through Jewish liturgy in Hebrew and popular styles in Arabic, a chance to be recognized as art music in the Western and global world.

\section{Affirming Homeness in Al-Andalus}

In a physical sense, Salomon Amzallag and his family settled and were uprooted from nearly twenty different homes in six different cities and four different countries. While establishing his career as a popular musician in Casablanca, Amzallag lived at at least eight different addresses between 1948 and 1959. After immigrating to Montreal, the Amzallag family lived at five different addresses, with a couple of sojourns in Ashdod, Israel, between 1967 and 2008. Interestingly, the Montreal addresses all remained within the neighborhood of Cote-des-Neiges, which has provided a home to large populations of migrants and refugees since the end of the Second World War and is today one of the most ethnically and linguistically diverse neighborhoods in Canada. In the post war period, a large number of Jewish families and institutions relocated from downtown, the Plateau, and Mile End to Cote-des-Neiges, including the Spanish and Portuguese Synagogue. As an observant Jew and cantor at an Orthodox congregation, it was important for Amzallag to live within walking distance of the synagogue as driving is prohibited on the Jewish Shabbat.

As Etan Diamond (2008, p. 133) has observed, Jewish suburban environments can contain a "web of religious microspaces", traceable in the walking patterns of Orthodox Jews. The Amzallag family was one of a few Moroccan Jewish families who settled around the Rue Victoria corridor in the 1960s, a neighborhood densely populated by Ashkenazi Jews at the time. In the movement between the house, synagogue, and stage-literally walking down the street, inviting congregants into his home and salon, or giving concerts at other local institutions-Amzallag created a homeness, inspired by his Moroccan Jewish background and based on the musical traditions of Al-Andalus. A sense of this homeness unfolds in Yolande Amzallag's recollection of her childhood in Montreal after moving with her family from Paris. The space of the synagogue was a large part of her family life, where she would take piano lessons, play in the choir loft, and perform with her father and siblings on stage (interview MJM 36:05-40:00). Amzallag drew on his identity as Samy Elmaghribi to bring "Oriental" melodies of Arabo-Andalusian music to the Jews from Iraq, Egypt, Iran, and Morocco who formed multiple congregations within the Spanish and Portuguese Synagogue. His performance of sacred and secular music transcended the presumed distinctions between sacred and secular space. For example, he would give concerts at the nearby Jewish Public Library to teach Ashkenazi Jews about Sephardic music and rituals. The synagogue and nearby park were a meeting place for Moroccan Jews and Ashkenazi Jews. Domestic and public spaces blurred in the trajectory between the synagogue and the house. The Amzallags converted their living room into a Moroccan salon, travelling to the "Arab quarter" of Montreal around Fullum Street to buy furniture. This "Oriental salon" became his home stage, where guests who knew the repertoire of Andalusian music would come to eat and sing along-whether they understood the Arabic lyrics or not. This homeness was reproduced and performed at the 2015 exhibition Sacré-Profane: Samy Elmaghirbi, where Muslim and Jewish fans also sang along in Arabic, regardless of comprehension. The Arabic language, enshrined in Andalusian music and culture, contained a homeness for the Moroccan Jews and Muslims as well as the broader North African diaspora in Montreal. This was nowhere more apparent than in the spaces created by the artist Samy Elmaghirbi. 
In their conversation about music, Barenboim and Said (2004) discuss a process of seeking home in music and literature. Barenboim sees the symphony as an allegory for the artist's exploration of the human condition. Examining Beethoven's Fourth Symphony from a purely harmonic level, he regards the opening long B-flat as a search for tonality $(2004$, p. 46). At first, it is unclear if the note is to be a B-flat or A-sharp, but by the end of the introduction, B-flat becomes the dominant chord and is affirmed again in the Allegro.

What is the purpose of establishing that? The purpose is to establish a very secure home of the music. Then, through a very astute enharmonic change-in other words, when B-flat and A-sharp become the same note-we suddenly get into totally foreign territory at the end of the development section. Why is it foreign? Because home has already been established. And this is what I would call the psychology of tonality. This is creating a sense of home, going to an unknown territory, and then returning. This is a process of courage and inevitability. There is the affirmation of the key-you want to call it the affirmation of the self, the comfort of the known territory-in order to go somewhere totally unknown and have the courage to get lost and, then, find again this famous dominant, in an unexpected way, that leads us back home. Isn't that a sort of parallel of the process that every human being had to go through in his inner life in order to first achieve the affirmation of what one is, then have the courage to let that identity go in order to find the way back. I think this is what music is about. I wouldn't say that it is always a criticism of society or of the human being, but it is a parallel of the inner process of the innermost thoughts and feelings of a human being. (2002, pp. 46-47)

Barenboim makes a very poetic comparison between the artistic journey and the exploration of the self. He attributes movement into foreign territory-getting lost—as an act of courage and inevitability, something distinctly audible in the Symphony. A home does not naturally exist, but must be established for the piece of music, like the artist himself. When Salomon Amzallag arrived in Montreal, his stardom was known only to a minority of North African and Middle Eastern music fans. As cantor at the Spanish and Portuguese Synagogue, he ventured into foreign territory. Through experimentation, he let go of the persona of Samy Elmaghribi and returned to him transformed, recreating himself as a Moroccan artist and professional Sephardic cantor in a Canadian environment.

Said's response to Barenboim draws a parallel between the musical journey within a symphony and Homer's Odyssey by describing a Beethoven piece as a search for tonality or a "home" note:

What you've described is an allegory that corresponds to one of the great myths that we find in literature, which is the myth of home, discovery, and return: the odyssey. There is absolutely a parallel between the explorations of Beethoven and of Homer, but having both the courage to leave and then to return is not just wandering away and coming back; there's a certain working out that is extremely intricate. Odysseus leaves home, leaves Penelope and his comforts in Ithaca. He goes to war and returns when it is over. But it's not just returning - that's where the fantastic power of the Odyssey is—but returning through a series of adventures after another, to which he's attracted. He could have just come home. But he is also a curious man. It's not just a matter of leaving home, it's leaving home and discovering things that attract you as well as threaten you. That's the point. He could have avoided his adventure with Polyphemus, the great one-eyed giant. But he felt he had to talk to him, he had to have a direct experience of challenging the fearsome creature, in order to finally return home, via these kinds of adventures, which is not the same as simply coming home after a day at the office. (2004, pp. 47-48)

Said reveals that the way home in the epic is created, left, and then returned to. It is contrasted with a homelessness Barenboim used to describe "the absence of tonality ... a kind of permanent exile because you're not going to come back" (2004, p. 49). Exile music and modernist literature for 
Barenboim and Said are examples of "homelessness". In the artist's courage to confront the various challenges he encountered on his journey and in his search for harmony between the contrasting forces (melodies) that he encountered, Samy Elmaghribi did not create exile music. His musical journey from Morocco through France, Algeria, Egypt, and the United States established a new home base in Montreal. There he invoked the mythology of Al-Andalus, which imagined the co-existence and cultural flourishing of Jewish, Christian, and Muslim cultures in the Iberian Peninsula. Al-Andalus provided a set of musical rules from which the artist could begin, journey away from, and return to as a changed person. This musical language was born from the crossing of cultures, a home that itself was the product of migration and innovation. The homeness of Al-Andalus was embodied in the oral tradition of the performer, and rearticulated through this artistic creation. The mythology of Al-Andalus becomes a moving home for Moroccans and North Africans in Montreal.

This essay began with a translation of the lyrics of Elmaghribi's "Salouni En nass" (People Ask $\mathrm{Me}$ ). While merging the sacred and secular, Amzallag performed his Arab culture in contemporary Quebec as a Jew, a model that challenges the conceptions of religion propagated by the prominent debate about the Charter of Values and the controversial 'Bill 21', which bans religious symbols. Revisiting Samy Elmaghribi's musical contribution from Morocco to contemporary Quebec also defies the contemporary reassessment of his work as Judeo-Arabic or Chgouri. The revival of this musical past today through these new labels (Judeo-Arabic or Chgouri) offers a narrative that dissociates Jews from Muslims, Jewishness from Arabness, and reinvents Samy Elmaghribi's work in light of the political present, a reality distinct from that of performing in Arabic as Jewish in the Morocco of the 1950s and 1960s. Yolande Amzallag learned from her father that one need not antagonize the majority to share one's value and culture with others. The tonality, the affirmation of Al-Andalus, and the Moroccan identity Salomon Amzallag embodied in his music was truly his most significant contribution as an Arab-Jewish artist.

Author Contributions: Both authors were equally invested in the archival research. The ethnographic data regarding the role of Samy Elmaghribi at the Spanish and Portuguese was collected by Jessica Roda. Each section has been written through a collaborative process. Both authors have read and agreed to the published version of the manuscript

Funding: This research received the support of the Fonds de recherche Sociéte et Culture du Québec and the Social Sciences and Humanities Research Council of Canada (SSHRC).

Conflicts of Interest: The authors declare no conflict of interest

\section{References}

Amiraux, Valérie, and David Koussens. 2014. Trajectoires de la neutralité. Montréal: Presses de l'Université de Montréal.

Amzallag, Yolande. 2017. Personal interview. Montreal: Museum of Jewish Montreal.

Barenboim, Daniel, and Edward Said. 2004. Parallels and Paradoxes: Explorations in Music and Society. New York: Vintage Books.

Bashkin, Orit. 2012. New Babylonians. A History of Jews in Modern Iraq. Stanford: Stanford University Press.

Benbassa, Esther, and Aron Rodrigue. 1995. Sephardi Jewry: A History of the Judeo-Spanish Community, 14th-20th Centuries. Berkley: University of California Press.

Bensimon, Jacques. 1977. 20 Ans Après. Montreal: National Film Board.

Bin-Nun, Yigal. 2014. The Reasons for the Departure of the Jews from Morocco 1956-1967: The Historiographical Problems. In Postwar Jewish Displacement and Rebirth. 1945-1967. Edited by Françoise S. Ouzan and Mandred Gerstendfeld. Leiden: Brill, pp. 196-211.

Boom, Aomar. 2013. Memories of Absence: How Muslims Remember Jews in Morocco. Stanford: Stanford University Press.

Cohen, Yolande. 2012. The Migrations of Moroccan Jews to Montreal: Memory, (Oral) History and Historical Narrative. Journal of Modern Jewish Studies 10: 345-62.

Cohen, Yolande, and Stephanie Tara Schwartz. 2017. Scholarship on Moroccan Jews in Canada: Multidisciplinary, Multilingual, and Diasporic. Journal of Canadian Studies 50: 592-612. [CrossRef] 
Davila, Carl. 2015. The Andalusi Turn: The Nuba in Mediterranean History. Mediterranean Studies 23: 149-69. [CrossRef]

Davis, Ruth. 2015. Musical Exodus: Al-Andalus and Its Jewish Diasporas. Lanham: Rowman \& Littlefield Publishers.

Diamond, Etan. 2008. Religious Microspaces in a Suburban Environment: The Orthodox Jews of Thornhill, Ontario. In Jewish Topographies: Visions of Space, Traditions of Place. Edited by Julia Brauch, Anna Lipphardt and Alexandra Nocke. London: Routledge, pp. 119-83.

El Haddaoui, Mohamed. 2014. La musique Judéo-Marocaine: Un Patrimoine en Partage. Casablanca: Editions La croisée des chemins.

Glasser, Jonathan. 2008. Genealogies of al-Andalus: Music and Patrimony in the Modern Maghreb. Ph.D. dissertation, University of Michigan, Ann Arbor, MI, USA.

Glasser, Jonathan. 2016. The Lost Paradise: Andalusi Music in Urban North Africa. Chicago: University of Chicago Press.

Goldberg, Harvey. 1996. Sephardi and Middle Eastern Jewries: History and Culture in the Modern Era (History $\mathcal{E}$ Culture in the Modern Era). Bloomington: Indiana University Press.

Gordon, Daniel. 2003. Juifs et musulmans. Belleville (Paris 20e) entre tolérance et conflit. Cahiers de la Méditérannée 67: 287-98. [CrossRef]

Gottreich, Emily. 2006. The Mellah of Marrakesh Jewish and Muslim Space in Morocco's Red City. Bloomington: Indiana University Press.

Gottreich, Emily. 2008. Historicizing the Concept of Arab Jews in the Maghrib. The Jewish Quarterly Review 98: 433-51. [CrossRef]

Gottreich, Emily. 2020. Jewish Morocco: A History from Pre-Islamic to Postcolonial Times. London: Bloomsbury.

Gronow, Pekka. 1981. The Record Industry Comes to the Orient. Ethnomusicology 25: 251-84. [CrossRef]

Gronow, Pekka, and Ilpo Saunio. 1999. An International History of the Recording Industry. London: Cassell.

Hobsbawm, Eric, and Terence Ranger. 1983. The Invention of Tradition. Cambridge: Cambridge University Press.

Horowitz, Amy. 2010. Mediterranean Israeli Music and the Politics of the Aesthetic. Detroit: Wayne State University Press.

Joseph, Norma. 2017. T'beet: Situating Iraqi Jewish Identity through Food. In Everyday Sacred: Religion in Contemporary Quebec. Edited by Hillary Kaell. Montreal: McGill-Queen's University Press.

Kaminsky, Catherine, and Simon Kurk. 1983. Le Nationalisme Arabe et le Nationalisme Juif. Paris: Presses Universitaires de France.

Lugassy, Charles. 1977. Samy Elmaghribi a la place des arts. Communaute Sepharade du Quebec 1: 4-5.

Marglin, Jessica. 2016. Across Legal Lines. Jews and Muslims in Modern Morocco. New Haven and London: Yale University Press.

Miles, William. 2012. Between Ashkenaz and Québécois: Fifty Years of Francophone Sephardim in Montréal. Diaspora 16: 29-66. [CrossRef]

Picard, François. 2001. La tradition comme réception et transmission (Qabala et Massorèt). In Approches Herméneutiques de la Musique. Edited by Jacques Viret. Strasbourg: Presses universitaires de Strasbourg, pp. 221-33.

Roda, Jessica. 2014. Jewish Performance as a Means for Constructing the Society of "Living Together". European Journal of Jewish Studies 8: 104-25. [CrossRef]

Roda, Jessica. 2015. Pop Stars as Ambassadors of Sephardic Culture at the Festival Sefarad in Montreal. Contemporary Jewry 15: 73-88. [CrossRef]

Roda, Jessica. 2018. Se réinventer au présent. Judéo-Espagnols de France, Famille, Communauté et Patrimoine Musical. Rennes: Presses Universitaires de Rennes.

Samy Elmaghribi Foundation. 1958. Musical Contract AT89982. February 26.

Samy Elmaghribi Foundation Archives. 1957. Musical Contract GL63483. April 4.

Schwartz, Stephanie Tara. 2017. Occupation and 20 ans après: Representing Jewish Dissent in Montreal, $1967-1977$. Canadian Jewish Studies 25: 60-78. [CrossRef]

Seroussi, Edwin. 2006. Andalusian Hebrew Strophic Poetry in the Religious Musical Repertoire of the Moroccan Jews. Paper presented at the Conference on Arabic and Hebrew Strophic Poetry and Its Romance Parallels, School of Oriental and African Studies [SOAS], London, UK, October 8-10. 
Seroussi, E. 2010. Elmaghribi, Samy (Amzallag). In Encyclopedia of Jews in the Islamic World. Edited by Norman A. Stillman. Available online: http://referenceworks.brillonline.com/entries/encyclopedia-of-jews-in-theislamic-world/*-SIM_0007080 (accessed on 12 November 2020).

Shannon, Jonathan Holt. 2015. Performing al-Andalus Music and Nostalgia across the Mediterranean. Bloomington: Indiana University Press.

Shohat, Ella. 2006. Rupture and Return: Zionist Discourse and the Study of Arab Jews. In Taboo Memories Diasporic Voices. Edited by Ella Shohat. Durham: Duke University Press, pp. 201-32.

Silver, Christopher. 2015. From Secular to Sacred: Rabbi David Buzaglo, Samy Elmaghribi, \& Paul Bowles' 1959 Field Recording. Jewish Maghribi Jukebox. Available online: http://jewishmorocco.blogspot.com/2015/12/fromsecular-to-sacred-rabbi-david.html (accessed on 12 November 2020).

Silver, Christopher. 2017. Jews, Music-Making, and the Twentieth Century Maghrib. Ph.D. dissertation, University of California, Los Angeles, CA, USA.

Silver, Christopher. 2020. The sounds of Nationalism: Music, Moroccanism, and the making of Samy Elmaghribi. International Journal Middle East Studies 52: 1-25. [CrossRef]

Publisher's Note: MDPI stays neutral with regard to jurisdictional claims in published maps and institutional affiliations.

(C) 2020 by the authors. Licensee MDPI, Basel, Switzerland. This article is an open access article distributed under the terms and conditions of the Creative Commons Attribution (CC BY) license (http://creativecommons.org/licenses/by/4.0/). 